\title{
Reduced diversity and increased virulence-gene carriage in intestinal enterobacteria of coeliac children
}

\author{
Ester Sánchez, Inmaculada Nadal ${ }^{1}$, Ester Donat ${ }^{2}$, Carmen Ribes-Koninckx ${ }^{2}$, \\ Miguel Calabuig ${ }^{3}$ and Yolanda Sanz*1
}

\author{
Address: ${ }^{1}$ Instituto de Agroquímica y Tecnología de Alimentos (CSIC), Apartado 73, 46100 Burjassot, Valencia, Spain, ${ }^{2}$ Hospital Universitario La \\ $\mathrm{Fe}$, Avenida Campanar 21, 40009 Valencia, Spain and ${ }^{3}$ Hospital General Universitario, Avenida Tres Cruces s/n 46014 Valencia, Spain \\ Email: Ester Sánchez - sanest@iata.csic.es; Inmaculada Nadal - cieina@iata.csic.es; Ester Donat - donat_est@gva.es; Carmen Ribes- \\ Koninckx - ribes_car@gva.es; Miguel Calabuig - calabuig_mig@gva.es; Yolanda Sanz* - yolsanz@iata.csic.es \\ * Corresponding author
}

Published: 4 November 2008

BMC Gastroenterology 2008, 8:50 doi:10.1 I86/147|-230X-8-50
Received: 14 May 2008

Accepted: 4 November 2008

This article is available from: http://www.biomedcentral.com/l47/-230X/8/50

(c) 2008 Sánchez et al; licensee BioMed Central Ltd.

This is an Open Access article distributed under the terms of the Creative Commons Attribution License (http://creativecommons.org/licenses/by/2.0), which permits unrestricted use, distribution, and reproduction in any medium, provided the original work is properly cited.

\begin{abstract}
Background: Coeliac disease is an immune-mediated enteropathology triggered by the ingestion of cereal gluten proteins. This disorder is associated with imbalances in the composition of the gut microbiota that could be involved in its pathogenesis. The aim of the present study was to determine whether intestinal Enterobacteriaceae populations of active and non-active coeliac patients and healthy children differ in diversity and virulence-gene carriage, so as to establish a possible link between the pathogenic potential of enterobacteria and the disease.
\end{abstract}

Methods: Enterobacteriaceae clones were isolated on VRBD agar from faecal samples of 31 subjects ( 10 active coeliac patients, 10 symptom-free coeliac patients and II healthy controls) and identified at species level by the API 20E system. Escherichia coli clones were classified into four phylogenetic groups A, BI, B2 and D and the prevalence of eight virulence-associated genes (typeI fimbriae [fimA], P fimbriae [papC], S fimbriae [sfaD/E], Dr haemagglutinin [draA], haemolysin [hlyA], capsule $\mathrm{KI}$ [neuB], capsule $\mathrm{K} 5[\mathrm{KfiC}$ and aerobactin [iutA]) was determined by multiplex PCR.

Results: A total of 155 Enterobacteriaceae clones were isolated. Non-E. coli clones were more commonly isolated in healthy children than in coeliac patients. The four phylogenetic $E$. coli groups were equally distributed in healthy children, while in both coeliac patients most commensal isolates belonged to group A. Within the virulent groups, B2 was the most prevalent in active coeliac disease children, while $D$ was the most prevalent in non-active coeliac patients. $E$ coli clones of the virulent phylogenetic groups (B2+D) from active and non-active coeliac patients carried a higher number of virulence genes than those from healthy individuals. Prevalence of $P$ fimbriae ( $p a p C)$, capsule K5 ( $\mathrm{sfaD} / \mathrm{E})$ and haemolysin (hlyA) genes was higher in $E$. coli isolated from active and nonactive coeliac children than in those from control subjects.

Conclusion: This study has demonstrated that virulence features of the enteric microbiota are linked to coeliac disease. 


\section{Background}

The human gastrointestinal tract is a complex ecosystem integrated by up to $10^{14}$ bacteria. These microorganisms may belong to more than 500 different bacterial species, although $99 \%$ of the total community consists of only 30-40 species. The intestinal microbiota plays an important role in human health as they contribute to inhibiting pathogen colonization, boosting the immune system, and metabolising nutrients [1-3]. Alterations in the intestinal microbiota have also been linked to inflammatory bowel diseases (IBD), such as ulcerative colitis and Crohn's disease, as well as to other immune-related disorders. IBD patients have been shown to carry higher concentrations of mucosa-associated bacteria than control groups. In addition, the gut microbiota of these patients was characterized by a decrease in protective bacteria, such as Bifidobacterium and Lactobacillus, and an increase in harmful bacterial groups like Bacteroides and Escherichia coli. This phenomenon has been named "dysbiosis" [4,5].

Escherichia coli was the first bacterial specie to be identified in human gastrointestinal samples. This widespread commensal Gram-negative bacterium found in the intestinal tract of healthy individuals can occasionally cause intestinal and extraintestinal diseases. The pathogenic potential of $E$. coli stains could be influenced by host endogenous factors, as well as by the genetic structure and ecological distribution of the strains in a particular host. Human infections by E. coli strains commonly occur in immunocompromised individuals or when the normal gastrointestinal barrier is broken [6], enabling opportunistic pathogens to evade host surveillance mechanisms. Phylogenetic studies based on the analysis of 38 metabolic enzymes, have shown that $E$. coli strains fall into four main phylogenetic groups, denominated "A", "B1", "B2" and "D" [7]. Strains causing extra-intestinal infections mainly belong to group B2, and to a lesser extent to group D, whereas commensal E. coli strains mostly belong to A and $\mathrm{B} 1$ groups [8]. E. coli strains belonging to B2 and D groups carry more virulence-associated genes than strains from A and B1 groups $[9,10]$. Therefore, the presence or absence of certain $E$. coli strains or an altered distribution of their relative abundance can enhance the pathogenic potential of the enteric population in predisposed individuals.

Coeliac disease is an immune-mediated enteropathology triggered by the ingestion of wheat-gluten and similar proteins of rye, barley and, probably, oats. Coeliac disease can be present at any age with a variety of clinical features; however, typical cases manifest in early childhood with gastrointestinal symptoms [11]. In coeliac patients, the inflammatory milieu caused by gluten antigens could lead to imbalances in gut microbial composition, characterised by higher numbers of Gram-negative bacteria and decreased numbers of beneficial Gram-positive bacteria, as compared to healthy individuals. In previous studies, E. coli proportions were significantly higher in duodenal biopsies of active coeliac patients than in controls [12]; moreover, a similar trend was detected in faeces although the differences were not so remarkable [13]. However, little is known about the possible association between enterobacterial population and coeliac disease pathogenesis.

The aim of the present study was to determine whether intestinal Enterobacteriaceae populations of active and non-active coeliac patients and healthy children differ in diversity and virulence-gene carriage, so as to establish a possible link between the pathogenic potential of enterobacteria and the disease.

\section{Methods \\ Subjects and sampling}

Thirty-one children were included in this study, 10 active coeliac patients, on a normal gluten-containing diet, showing clinical symptoms of the disease, positive coeliac serology markers and signs of severe enteropathy by duodenal biopsy examination (mean age 3.86 years, range 1.0-8.86 years); 10 symptom-free coeliac patients (nonactive coeliac), who had been on a gluten-free diet for 12 years (mean age 6.2 years, range $1.0-12.0$ years); and 11 healthy children without known food intolerance (mean age 3.51 years, range $0.1-7.75$ years). None of the children included in the study had been treated with antibiotics for at least 1 month before the sampling time. Faecal samples were collected and immediately stored at $4^{\circ} \mathrm{C}$, under anaerobic conditions (AnaeroGen, Oxoid, Hampshire, UK), and analysed in less than 12 hours. The study protocol was approved by the local Ethics Committee, and children were enrolled in the study after written informed consent was obtained from their parents.

\section{Isolation and identification of Enterobacteriaceae clones from faeces}

Faecal samples ( $2 \mathrm{~g}$ wet weight) were 10 -fold diluted in phospahate-buffered saline (PBS, $130 \mathrm{mM}$ sodium chloride, $10 \mathrm{mM}$ sodium phosphate, [pH 7.2]), and homogenized in a Lab Blender 400 Stomacher (Seward Medical, London, UK). Serial dilutions were made in PBS and aliquots were plated on Violet Red Bile Dextrose Agar, VRBD (Scharlau, Barcelona, Spain) and incubated under aerobic conditions at $37^{\circ} \mathrm{C}$ for 48 hours. Then, five individual Enterobacteriaceae-like colonies differing in size, shape, colour or mucoid appearance on VRBD agar were isolated and subcultured in Plate Count Agar (Scharlau, Barcelona, Spain) under aerobic conditions at $37^{\circ} \mathrm{C}$ for 24 hours. The identity of the presumptive Enterobacteriaceae isolates was confirmed by conventional microbiological methods, including colony and cellular morphology and Gram staining. The selected isolates were further identified at species level by using the API20E system (BioMerieux, 
Lyon, France), in order to select E. coli clones and non-E. coli clones.

\section{Phylogenetic classification and virulence-associated gene carriage of E. coli isolates}

Escherichia coli isolates were assigned to one of the four phylogenetic groups A, B1, B2 or D by a triplex PCR technique as previously described [14]. The $25 \mu$ l PCR mixture consisted of $10 \mathrm{mM}$ Tris-HCl (pH 8.3), $2.5 \mathrm{mM} \mathrm{MgCl}_{2}, 1$ $\mu \mathrm{M}$ of each primer pair for the genes ChuA, YjaA and TspE4C2, $200 \mu \mathrm{M}$, dNTPs and 2.5 U of Taq polymerase (Ecotaq, ECOGEN, Spain). A piece of a bacterial colony was collected directly from a plate and added to the reaction mixture as a source of DNA. The PCR programme was as follows: initial denaturalization at $94^{\circ} \mathrm{C}$ for $4 \mathrm{~min}$; and 30 cycles of $5 \mathrm{~s}$ at $94^{\circ} \mathrm{C}, 10 \mathrm{~s}$ at $59^{\circ} \mathrm{C}$; and a final extension step of $5 \mathrm{~min}$ at $72^{\circ} \mathrm{C}$. The PCR products were separated in a $2 \%$ agarose gel electrophoresis and visualised by ethidium-bromide staining. The isolates were assigned to phylogenetic groups as follows: $\mathrm{ChuA}^{+} \mathrm{YjaA}^{+}$, group $\mathrm{B} 2$; $\mathrm{ChuA}^{+} \mathrm{YjaA}^{-}$, group $\mathrm{D}$; ChuA- TspE4C2+ group B1; ChuATspE4C2- group A.

The same isolates were also characterized by two sets of multiplex PCR as described by Nowrouzian et al. (2001) [15]. The first PCR detected the presence of the following virulence-associated genes: fimA (type-1 fimbriae), $p a p C$ (P fimbriae), sfaD/E (S fimbriae) and $d r a A$ (Dr haemagglutinin). The second PCR detected the presence of the following genes: hlyA (haemolysin), neuB (capsule K1), KfiC (capsule K5) and iutA (aerobactin). The $25 \mu \mathrm{l} \mathrm{PCR}$ reaction mixture consisted of $10 \mathrm{mM}$ Tris $\mathrm{HCl}(\mathrm{pH} \mathrm{8.3)}$, $1.5 \mathrm{mM}$ of $\mathrm{MgCl}_{2}$ for the first multiplex PCR and $2.0 \mathrm{mM}$ $\mathrm{MgCl}_{2}$ for the second multiplex PCR, $0.45 \mu \mathrm{M}$ of each primer, $100 \mu \mathrm{M}$ dNTPs and $2.5 \mathrm{U}$ of Taq polymerase (Ecotaq, ECOGEN, Spain). A piece of a bacterial colony was used as a source of DNA as indicated above.

\section{Statistical analyses}

Differences in prevalence of different species, phylogenetic groups or virulence genes were established by applying the chi-square test, and when appropriate by the twotailed Fisher's exact test and Kolmogorov-Smirnof test. In each case, analyses were carried out with the Statgraphics software (Manugistics, Rockville, MD), and statistical differences were established at $P$ value below 0.05 .

\section{Results}

\section{Diversity of Enterobacteriaceae and E. coli clones from} coeliac and healthy children

Of the 31 individuals analyzed in this study, only 14 (45\%) carried Enterobacteriaceae species other than E. coli. The latter species was always recovered in healthy individuals and in eight of them (73\%) at least one other non-E. coli species was detected. Non-E. coli species were detected in only four (40\%) active and two non-active coeliac patients $(20 \%)$. Non-E. coli clones were recovered more abundantly in healthy children than in non-active coeliac patients $(P=0.03)$.

Citrobacter freundii, Enterobacter agglomerans, Klebsiella oxytoca and Escherichia vulneris were identified in healthy children harbouring non-E. coli species. Klyuvera spp, Enterobacter cloacae, Citrobacter freundii, Shigella spp, Chryseomonas luteola and Klebsiella oxytoca were also isolated in active coeliac disease children and Klebsiella oxytoca, Aeromonas hydrophila/caviae and Klebsiella pneumoniae were identified in non-active coeliac patients.

\section{Phylogenetic classification of E. coli clones from coeliac and healthy children}

The phylogenetic classification of E. coli clones isolated from faeces of the three groups of children is shown in Figure 1. The total number of isolates belonging to both commensal groups $(\mathrm{A}+\mathrm{B} 1)$ and the total number of isolates belonging to both virulent groups $(\mathrm{B} 2+\mathrm{D})$ did not differ significantly between the three populations of children under study. However, differences were observed in the abundance of each of the four phylogenetic groups. In healthy children, A and B1 E. coli groups were equally distributed, while in active and non-active coeliac patients almost all the commensal isolates belonged to group A $(P$ $<0.001$ ), revealing lower $E$. coli diversity in clones from coeliac patients. Significant differences were found between the prevalence of virulent clones isolated from active or non-active coeliac patients and healthy children. In healthy individuals, virulent isolates were equally represented by both groups B2 and D. In contrast, group B2 was the main virulent group isolated from active coeliac patients $(P=0.0002)$, and group $\mathrm{D}$ was that most common in non-active coeliac patients $(P=0.0001)$.

\section{Virulence-associated gene carriage in E. coli clones from coeliac and healthy children}

The prevalence of virulence-associated genes in commensal groups $(\mathrm{A}+\mathrm{B} 1)$ and virulent groups $(\mathrm{B} 2+\mathrm{D})$ of $E$. coli clones isolated from active and non-active coeliac and control children are shown in Table 1. Overall, virulent $E$. coli clones (B2 + D) from healthy individuals carried fewer virulence-associated genes than those from active and non active coeliac patients. Both active and non-active coeliac patients had a significantly higher prevalence of $\mathrm{P}$ fimbriae gene $(p a p C),(P=0.002-0.050)$ than healthy controls. In addition, type- 1 fimbriae gene (fim $A$ ) prevalence was higher in both active and non-active coeliac patients than in healthy controls but the differences were not significant $(P=0.06)$. Capsule $\mathrm{K} 1$ gene $(n e u B)$ was also more prevalent in both active and non-active coeliac patients than in healthy controls; however, differences were not significant. Capsule $\mathrm{K} 5$ gene ( $\mathrm{KfiC}$ ) was significantly more common in virulent $E$. coli isolates from active coeliac children than in those from non-active coeliac children $(P$ 
A

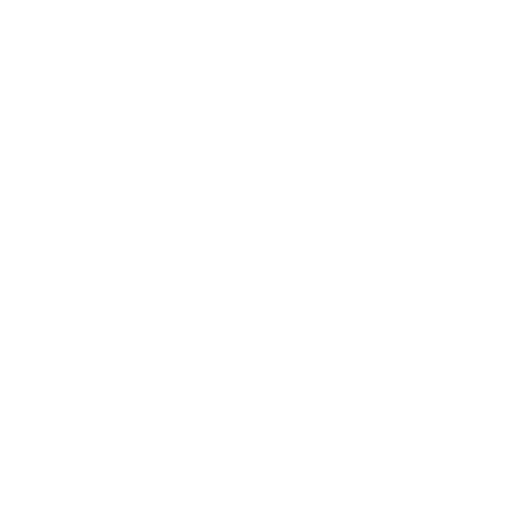

B

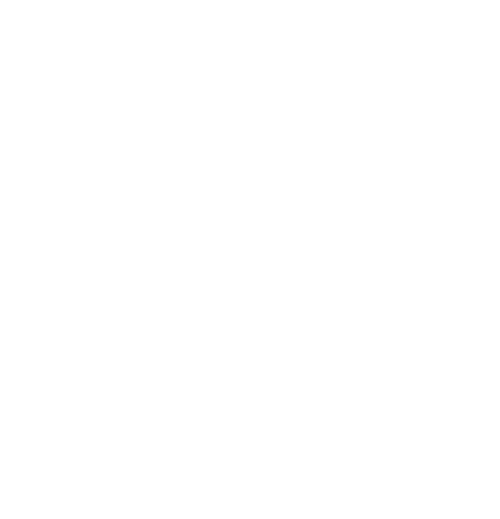

C

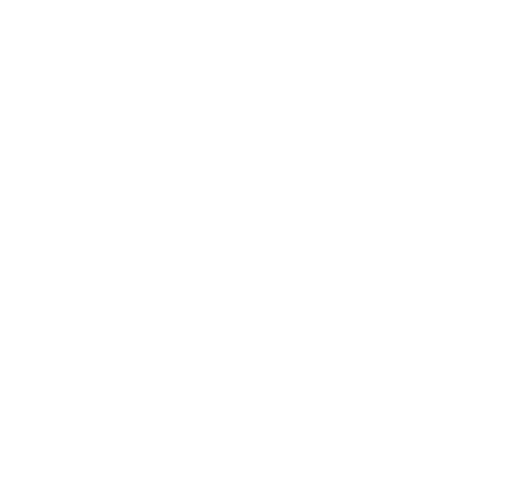

\section{A \\ B1 \\ B2 \\ D}

Figure I

Distribution of the phylogenetic $E$. coli groups in active coeliac patients (A), non-active coeliacs (B) and healthy children (C). A and BI commensal groups and B2 and D virulent groups. Data are expressed as percentage (number of positive clones/number of total analysed clones).

$=0.02)$, suggesting its association with the active phase of the disease. Haemolysin gene $(h l y A)$ prevalence was higher in both coeliac disease subjects than in healthy controls, showing significant differences between nonactive coeliac disease patients and controls $(P=0.01)$. In commensal groups $(\mathrm{A}+\mathrm{B} 1)$, S fimbriae $(s f a D / E)$ gene prevalence was significantly higher in non-active coeliac patients than in healthy and active coeliac patients $(P=$ 0.04 and $P=0.02)$, whereas capsule $\mathrm{K} 1$ gene (neuB) was significantly less common in commensal $E$. coli isolates

Table I: Prevalence of virulence-associated genes in A+B I (commensal) and B2+D (virulent) E. coli clones isolated from active and non-active coeliac disease patients and healthy children

\begin{tabular}{|c|c|c|c|c|c|c|}
\hline \multirow[t]{2}{*}{ Virulence factor (gene) } & \multicolumn{3}{|c|}{ Virulent B2 + D clones (\%)* } & \multicolumn{3}{|c|}{ Commensal A + BI clones (\%)* } \\
\hline & $\begin{array}{l}\text { Active coeliac } \\
\quad(n=23)\end{array}$ & $\begin{array}{l}\text { Non-active coeliac } \\
\quad(n=23)\end{array}$ & $\begin{array}{l}\text { Healthy } \\
(n=2 I)\end{array}$ & $\begin{array}{l}\text { Active coeliac } \\
\quad(n=17)\end{array}$ & $\begin{array}{c}\text { Non-active coeliac } \\
\quad(n=19)\end{array}$ & $\begin{array}{l}\text { Healthy } \\
(n=19)\end{array}$ \\
\hline $\begin{array}{l}\text { Type I fimbriae } \\
(\text { fim A) }\end{array}$ & $18(78)^{a}$ & $18(78)^{a}$ & $10(48)^{a}$ & II $(65)^{a}$ & $14(82)^{a}$ & $16(84)^{\mathrm{a}}$ \\
\hline $\begin{array}{l}\text { S fimbriae } \\
(s f a D / E)\end{array}$ & $8(35)^{a}$ & $9(39)^{\mathrm{a}}$ & $8(38)^{a}$ & $0 \mathrm{a}$ & $6(35) b$ & $I(5)^{a}$ \\
\hline $\begin{array}{l}\text { P fimbriae } \\
(p a p C)\end{array}$ & $5(22)^{a}$ & $9(39)^{a}$ & $0^{b}$ & $0^{\mathrm{a}}$ & $0^{a}$ & $4(21)^{a}$ \\
\hline $\begin{array}{l}\text { Dr haemagglutinin } \\
(\mathrm{draA})\end{array}$ & $0^{\mathrm{a}}$ & $0^{a}$ & $0^{\mathrm{a}}$ & $0^{a}$ & $0^{a}$ & $0^{\mathrm{a}}$ \\
\hline $\begin{array}{l}\text { Haemolysin } \\
\text { (hlyA) }\end{array}$ & $5(22)^{a b}$ & $9(39)^{\mathrm{b}}$ & $I(5)^{a}$ & $0^{a}$ & $I(6)^{a}$ & $4(2 I)^{a}$ \\
\hline $\begin{array}{l}\mathrm{KI} \\
\text { (neuB) }\end{array}$ & $8(35)^{\mathrm{a}}$ & $5(22)^{a}$ & $5(24)^{a}$ & $0 \mathrm{a}$ & $10(59) b$ & $8(42)^{b}$ \\
\hline $\begin{array}{l}\mathrm{K} 5 \\
(\mathrm{KfiC})\end{array}$ & $6(26)^{a}$ & $0^{\mathrm{b}}$ & $2(10)^{a b}$ & $0^{a}$ & $0^{a}$ & $I(5)^{\mathrm{a}}$ \\
\hline $\begin{array}{l}\text { Aerobactin } \\
\text { (iutA) }\end{array}$ & $4(17)^{a}$ & $4(17)^{\mathrm{a}}$ & $7(33)^{a}$ & $I(6)^{\mathrm{a}}$ & $6(35)^{\mathrm{ab}}$ & $12(63) b$ \\
\hline
\end{tabular}

*Different letters ( $a$ to $b$ ) in the same row and within the same phylogenetic group (virulent $B 2+D$ or commensal $A+B I$ ) indicate significant differences in the gene-carriage. 
from active coeliac children than in the other groups $(P<$ 0.001). Moreover, aerobactin gene (iutA) was more common in commensal $E$. coli clones isolated from healthy controls than those from active coeliac individuals $(P<$ $0.001)$.

Figure 2 shows the prevalence of virulence-associated genes in commensal groups $(\mathrm{A}+\mathrm{B} 1)$ and virulent groups $(\mathrm{B} 2+\mathrm{D})$ of $E$. coli clones isolated in this study. S fimbriae $(s f a D / E), P$ fimbriae (papC), haemolysin (hlyA) and capsule $\mathrm{K} 5(\mathrm{KfiC})$ genes were significantly more common in virulent $E$. coli clones than in commensal clones $(\mathrm{P}<$ 0.05). Accordingly, P fimbriae ( $(p a p C)$, haemolysin ( $h l y A)$ and capsule $\mathrm{K} 5(\mathrm{KfiC})$ genes prevalence was associated with one or both coeliac patient groups, which would suggest that $E$. coli clones from patients have a higher pathogenic potential than those from controls. No differences were detected in the carriage of type 1 fimbriae $(\operatorname{fim} A)$, Dr haemagglutinin $(d r a A)$, capsule $\mathrm{K} 1(n e u B)$ and aerobactin (iutA) genes between the commensal and virulent $E$. coli groups. Furthermore, the distribution of these genes was either less remarkable or bore no relationship with coeliac disease.

\section{Discussion}

Significant differences were revealed in the diversity and virulence-gene carriage of Enterobacteriaceae and E. coli clones isolated from faeces of active and non-active coeliac patients and healthy controls, suggesting that this bacterial group could be primarily or secondarily involved in coeliac disease.

E. coli was the most common member of the Enterobacteriaceae family isolated from human faecal samples of healthy and coeliac disease children. This result is consistent with a previous study of 49 coeliac and healthy children, in which the main Enterobacteriaceae species detected was E. coli. In the aforementioned study, the ratio of $E$. coli to Enterobacteriaceae was greater in active coeliac children than in healthy controls [13]. Furthermore, biopsy specimens taken from paediatric patients with inflammatory bowel disease also revealed that $E$. coli was the most common Enterobacteriaceae species detected in MacConkey agar [16]. Thus, a reduction in the relative abundance of non-E. coli species is associated with coeliac disease and could favour the predominance of harmful clones in the gut ecosystem.

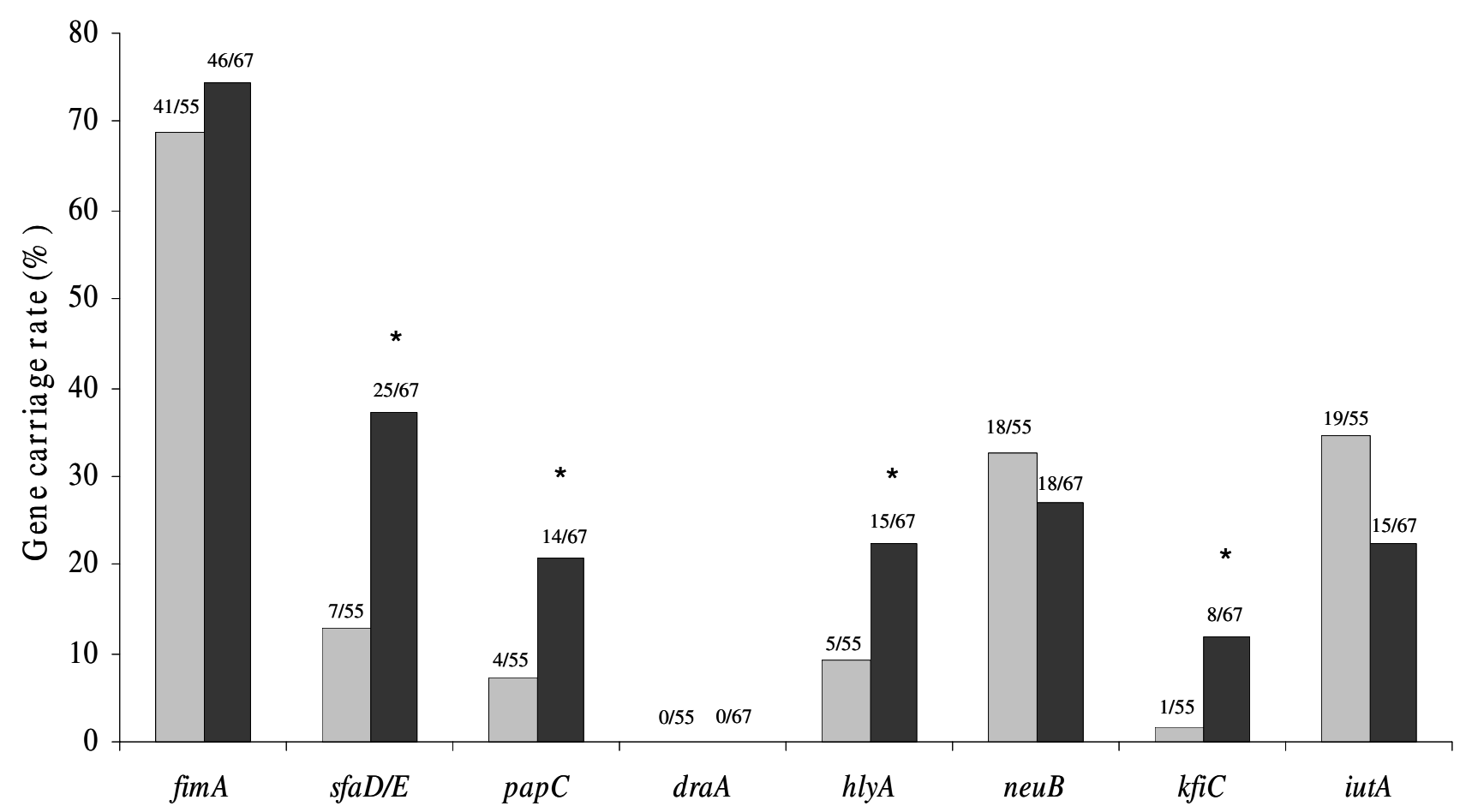

Figure 2

Prevalence percentage of virulence-associated genes in A+B I commensal (grey bars) and B2+D virulent (black bars) $E$. coli groups. Data are expressed as percentage (number of positive clones/number of total analysed clones). *Significant difference at $P<0.05$ by applying the Fisher's exact test. 
Although several Enterobacteriaceae colonies were often selected from a sample, because they differed morphology and were suspected to represent different strains, they often turned out to be identical regarding their phylogenetic classification and virulence-associated gene patterns, usually some of them represented the same clone. This can be explained by the fact that only one clone usually dominates human gastrointestinal gut so that the other clones are not detectable [17].

The phylogenetic groups A, B1, B2 and D were found in different proportions in healthy, active coeliac and nonactive coeliac patients. This fact also suggests links between lower diversity of intestinal $E$. coli population and coeliac disease. In healthy children, isolates of each of the four groups were found in equal proportions. By contrast, isolates belonging to groups A and B2, followed by those of group D dominated the composition of E. coli microbiota in active coeliac children, while integrants of group B1 were not isolated; group D was the most common in non-active coeliac disease, followed by groups $\mathrm{A}$, $\mathrm{B} 2$, and B1. These results reflect imbalances in the composition of the four $E$. coli phylogenetic groups in coeliac disease children, revealing the most remarkable differences between non-active coeliac patients and healthy controls. In patients with IBD, such as Crohn's disease and ulcerative colitis, B2 and D phylogenetic groups were more prevalent than in the control group. Moreover, a relationship was established between the presence of serine protease autotransporter proteins (SPATE) or adhesins in $\mathrm{B} 2+\mathrm{D}-$ positive E. coli isolates [18]. In active coeliac patients, the dominance of group B2 virulent clones could provide pathogenic inflammatory factors either causative or consequence of the inflammatory status associated with gluten intake in the active phase of this disorder creating a vicious circle. Nowrouzian et al. [19] concluded that group D strains preferentially colonize infants with less complex intestinal microbiota, since this group is more abundant than others in one-year-old infants. Both genetic make-up and gluten-free diet could contribute to changes in the gut milieu of non-active coeliac patients, leading to a predominant colonization of the virulent $\mathrm{D}$ group in detriment to the others. In fact, lower total bacterial populations have been detected in duodenal samples taken from this population group when compared with active coeliac patients and controls [12].

Overall, E coli clones of the virulent phylogenetic groups $(\mathrm{B} 2+\mathrm{D})$ isolated from active and non-active coeliac patients, carried a higher number virulent genes than those from healthy controls. A higher prevalence of $\mathrm{P}$ fimbriae gene ( $p a p C$ ) was found in coeliac patients as compared to healthy children, regardless of the phase of this disorder; however, the association of type-1 fimbriae $(f i m A)$ and S fimbriae $(s f a D / E)$ gene carriage with coeliac disease was not so evident. Significant differences in the carriage of type-1 fimbriae ( $\operatorname{fim} A$ ) gene were not detected in the group of children under study but $E$. coli clones from active and non-active coeliac disease isolates tended to carry fewer type-1 fimbriae (fimA) genes than those from healthy children. Previous studies have indicated that the proportion of type-1 fimbriated E. coli is lower in IgA-deficient subjects than in control individuals $[20,21]$ and this may also be the case for coeliac disease patients since this disease is associated with IgA deficiency. E. coli adhesins, including $P$ fimbriae, confer mannose-resistant (MR) adherence to intestinal epithelial cells. MR adhesions are well-know virulence factors in urinary-tract infection, septicaemia and meningitis. Strains that persist in the human intestinal microbiota (resident strains) are more often P fimbriated, whereas S fimbriated E. coli are not associated with long-term persistence in the gut of healthy individuals $[20,22]$. Thus, the significantly higher prevalence of $\mathrm{P}$ fimbriae E. coli clones in treated and untreated coeliac patients constitutes a novel link between gut microbiota and coeliac disease, and revealed that gut health may be compromised in these subjects, even when subjected to a gluten-free diet.

A higher prevalence of capsular $\mathrm{K} 5$ gene $(\mathrm{kfiC})$ of $\mathrm{E}$. coli clones belonging to the virulent groups was associated with active coeliac disease, while a similar but less remarkable trend was found in non-active coeliac patients, as compared to controls. Capsular polysaccharides are known to render bacterial surfaces hydrophilic and negatively charged, making the bacterium resistant to entrapment in mucus. In addition, capsules contribute to virulence by protecting bacteria from phagocytosis and possibly from serum killing, in part by blocking activation of the alternative complement pathway $[23,15]$.

Moreover, a higher prevalence of the haemolysin ( $h l y A)$ gene in $E$ coli clones of the virulent groups was associated with non-active coeliac patients in particular. $\alpha$-Haemolysin is the most common cytolytic protein secreted by haemolytic E. coli strains. Haemolysin activity might contribute to persistence by attacking enterocytes and releasing nutrients for the bacteria. In fact, E. coli appears to use membrane lipids as its main nutrient source in the large intestine $[23,24]$.

It has also been confirmed that $E$. coli clones of the virulent groups $(\mathrm{B} 2+\mathrm{D})$ carried more virulent-associated genes than those of commensal groups $(\mathrm{A}+\mathrm{B} 1)$, with the exception of the aerobactin gene (iutA). Remarkably, genes for $\mathrm{S}(s f a D / E)$ and $\mathrm{P}$ fimbriae ( $p a p C), \mathrm{K} 5$ capsule $(\mathrm{kfiC})$ and haemolysin $(h l y A)$ were significantly more common in virulent $E$. coli clones than in commensal strains of our population groups. In agreement, genes coding for virulence-associated genes have been found more frequently in pathogenic strains than in commensal strains $[8,23]$. In addition, virulent $E$. coli isolates $(\mathrm{B} 2+\mathrm{D})$ 
have previously been shown to carry virulence-associated genes more commonly than commensal clones $[10,25,26]$. Virulence-associated genes are usually encoded on pathogenicity islands (PAIs) providing a mechanism for coordinated horizontal transfer of virulence genes, thus favouring dissemination of pathogenic determinants, as could be the case in the gut ecosystem of coeliac patients [27].

\section{Conclusion}

This study has demonstrated changes in Enterobacteriaceae diversity and increases in virulence-gene carriage in $E$. coli clones isolated from coeliac patients when compared to those from healthy controls. Thus, the results support the hypothesis that dysbiosis may constitute a virulence factor contributing to pathogenesis and full expression of coeliac disease. Further studies should be carried out to correlate the virulence gene carriage with specific pathogenic roles that $E$. coli clones could play in this disorder.

\section{Competing interests}

The authors declare that they have no competing interests.

\section{Authors' contributions}

ES and IN carried out the microbiological, molecular and statistical analyses. ED, CR and MC collected the samples and clinical data. YS conceived and coordinate the study. YS and ES wrote the manuscript. All authors read, reviewed and approved the final version of the manuscript.

\section{Acknowledgements}

This work was supported by grants AGL2005-05788-C02-0I and Consolider Fun-C-Food CSD2007-00063 from the Spanish Ministry of Science and Education (MEC). The scholarship to E. Sánchez from Danone S.A. is fully acknowledged.

\section{References}

I. Wang M, Ahrné S, Jeppsson B, Molin G: Comparison of bacterial diversity along the human intestinal tract by direct cloning and sequencing of I6S rRNA genes. FEMS Microbiol Ecol 2005, 54(2):2|9-3|.

2. Flint HJ, Duncan SH, Scott KP, Louis P: Interactions and competition within the microbial community of the human colon: links between diet and health. Environ Microbiol 2007, 9(5): II0I-II.

3. Rajiliæ-Stojanoviæ $M$, Smidt $H$, de Vos WM: Diversity of the human gastrointestinal tract microbiota revisited. Environ Microbiol 2007, 9(9):2 I25-36.

4. Neut C, Bulois P, Desreumaux P, Membré JM, Lederman E, Gambiez L, Cortot A, Quandalle P, van Kruiningen H, Colombel JF: Changes in the bacterial flora of the neoterminal ileum after ileocolonic resection for Crohn's disease. Am J Gastroenterol 2002, 97(4):939-46.

5. Swidsinski A, Weber J, Loening-Baucke V, Hale LP, Lochs H: Spatial organization and composition of the mucosal flora in patients with inflammatory bowel disease. J Clin Microbiol 2005, 43(7):3380-9.

6. Rolhion N, Darfeuille-Michaud A: Adherent-invasive Escherichia coli in inflammatory bowel disease. Inflamm Bowel Dis 2007, I 3(I 0): | 277-83.

7. Herzer PJ, Inouye S, Inouye M, Whittam TS: Phylogenetic distribution of branched RNA-linked multicopy single-stranded
DNA among natural isolates of Escherichia coli. I Bacteriol 1990, I72(I I):6I75-8I.

8. Picard B, Garcia JS, Gouriou S, Duriez P, Brahimi N, Bingen E, Elion J, Denamur $E$ : The link between phylogeny and virulence in Escherichia coli extraintestinal infection. Infect Immun 1999, 67(2):546-53.

9. Nowrouzian FL, Adlerberth I, Wold AE: Enhanced persistence in the colonic microbiota of Escherichia coli strains belonging to phylogenetic group B2: role of virulence factors and adherence to colonic cells. Microbes Infect 2006, 8(3):834-40.

10. Sabaté M, Moreno E, Pérez T, Andreu A, Prats G: Pathogenicity island markers in commensal and uropathogenic Escherichia coli isolates. Clin Microbiol Infect 2006, I 2(9):880-6.

II. Fasano A, Catassi C: Coeliac disease in children. Best Pract Res Clin Gastroenterol 2005, I9(3):467-78.

12. Nadal I, Donat E, Ribes-Koninckx C, Calabuig M, Sanz Y: Imbalance in the composition of the duodenal microbiota of children with coeliac disease. J Med Microbiol 2007, 56(Pt I 2): I669-74.

13. Collado MC, Calabuig M, Sanz Y: Differences between the fecal microbiota of coeliac infants and healthy controls. Curr Issues Intest Microbiol 2007, 8(I):9-I4.

14. Clermont $\mathrm{O}$, Bonacorsi S, Bingen E: Rapid and simple determination of the Escherichia coli phylogenetic group. Appl Environ Microbiol 2000, 66( I 0):4555-8.

15. Nowrouzian F, Adlerberth I, Wold AE: $\mathbf{P}$ fimbriae, capsule and aerobactin characterize colonic resident Escherichia coli. Epidemiol Infect 200I, I 26(I): I I-8.

16. Conte MP, Schippa S, Zamboni I, Penta M, Chiarini F, Seganti L, Osborn J, Falconieri P, Borrelli O, Cucchiara S: Gut-associated bacterial microbiota in paediatric patients with inflammatory bowel disease. Gut 2006, 55(12): 1760-7.

17. Lidin-Janson G, Kaijser B, Lincoln K, Olling S, Wedel H: The homogeneity of the faecal coliform flora of normal school-girls, characterized by serological and biochemical properties. Med Microbiol Immunol 1987, I 64:247-253.

18. Kotlowski R, Bernstein CN, Sepehri S, Krause DO: High prevalence of Escherichia coli belonging to the B2+D phylogenetic group in inflammatory bowel disease. Gut 2007, 56(5):669-75.

19. Nowrouzian FL, Wold AE, Adlerberth I: Escherichia coli strains belonging to phylogenetic group B2 have superior capacity to persist in the intestinal microflora of infants. I Infect Dis 2005, I 9 I(7): 1078-83.

20. Friman V, Adlerberth I, Connell H, Svanborg C, Hanson LA, Wold AE: Decreased expression of mannose-specific adhesins by Escherichia coli in the colonic microflora of immunoglobulin A-deficient individuals. Infect Immun 1996, 64(7):2794-8.

21. Friman V, Nowrouzian F, Adlerberth I, Wold AE: Increased frequency of intestinal Escherichia coli carrying genes for $S$ fimbriae and haemolysin in IgA-deficient individuals. Microb Pathog 2002, 32(I):35-42.

22. Nowrouzian FL, Friman V, Adlerberth I, Wold AE: Reduced phase switch capacity and functional adhesin expression of type Ifimbriated Escherichia coli from immunoglobulin A-deficient individuals. Infect Immun 2007, 75(2):932-40.

23. Johnson JR: Virulence factors in Escherichia coli urinary tract infection. Clin Microbiol Rev 199I, 4(I):80-128.

24. Nowrouzian F, Hesselmar B, Saalman R, Strannegard IL, Aberg N, Wold AE, Adlerberth I: Escherichia coli in infants' intestinal microflora: colonization rate, strain turnover, and virulence gene carriage. Pediatr Res 2003, 54(I):8.

25. Johnson JR, Delavari P, Kuskowski M, Stell AL: Phylogenetic distribution of extraintestinal virulence-associated traits in Escherichia coli. J Infect Dis 200I, I 83(I):78-88. Epub 2000 Nov 22

26. Boyd EF, Hartl DL: Chromosomal regions specific to pathogenic isolates of Escherichia coli have a phylogenetically clustered distribution. J Bacteriol 1998, I 80(5): I I 59-65.

\section{Pre-publication history}

The pre-publication history for this paper can be accessed here:

http://www.biomedcentral.com/1471-230X/8/50/pre pub 